\title{
Oedometer tests - an aid in determination of the geological load history?
}

\author{
GRETE THORSEN
}

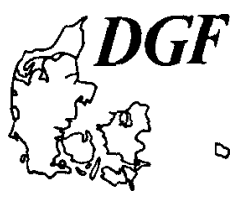

Thorsen, G.: Oedometer tests - an aid in determination of the geological load
history? Bulletin of the Geological Society of Denmark. Vol. $43 \mathrm{pp} .41-50$.
Co-penhagen 1996-07-14. httøs://doi.org/10.37570/bgsd-1996-43-05

The paper describes the results of oedometer tests carried out with samples from Eemian fresh-water deposits and the methods used to determine the preconsolidation pressure from the test results. The influence of creep in the material on the apparent preconsolidation pressure is estimated from a model set up by Moust Jacobsen in 1992. The test results do not show any significant difference in the determined values of the overconsolidation ratio (OCR) for the samples from Hollerup and Solsø, east and west of the main stationary line for the last ice sheet in Weichselian, respectively. The results, however, tell nothing about the kind of actions, which has caused the overconsolidation. The determined OCR-values might be due to previous ice caps but a big difference in the two values from Sols $\varnothing$ indicates a considerableinfluence fromother actions. The sediments from Hollerup and Sols $\varnothing$ are not identical, and the effect of temperature, chemical and biological processes on the apparent preconsolidation pressure has not been evaluated.

Grete Thorsen, Aalborg University, Department of Civil Engineering, Sohngaardsholmsvej 57, DK-9000 Aalborg, Denmark, June 7th, 1996.

\section{Introduction}

Geological investigations by Larsen and Kronborg (1994) concerning the ice sheets during the Weichselian ice age seem to indicate that the Eemian deposits in the western and central part of Jutland have been covered by ice sheets.

The purpose of the actual investigation has been to carry out oedometer tests on samples of Eemian freshwater clay deposits from east and west of the main stationary line for the last ice sheet in Weichselian in order to see if the results show a significant difference in the determined preconsolidation pressure.

Fig. 1 shows localities where deposits from Eemian are found (Larsen \& Kronborg 1994). In April 1995 samples were extracted from fresh-water deposits in the kieselguhr pit at Hollerup and in May 1995 a boring sponsored by Kampsax-Geodan, Holstebro, was carried out at Sols $\emptyset$, and samples were extracted from Eemian fresh-water deposits (Fig. 1).

Oedometer tests have been carried out with two samples of fresh-water clay-mud from Hollerup and with 2 samples of fresh-water clay-mud from Solsø.
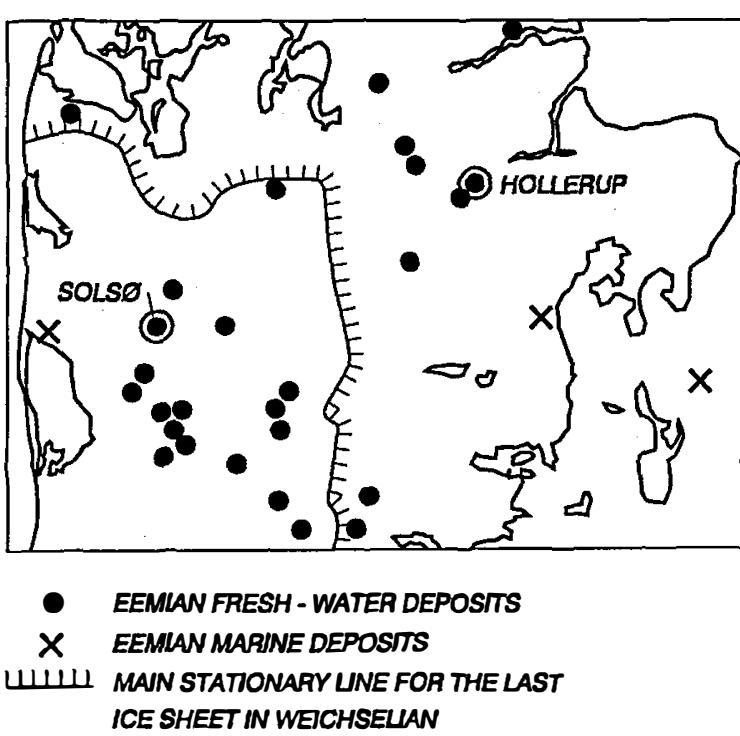

Fig. 1. Site plan. Hollerup and Solsø 
In 1992 Moust Jacobsen set up a model to separate creep and consolidation deformations during the consolidation process (Moust Jacobsen 1992a, b). The model was set up for slightly preconsolidated clay till, but has also been used for other kinds of clay (Thorsen 1995a, b). Use of this model allows the possibility of estimating whether creep in the material since the time of deposition may have caused the actual preconsolidation pressure or whether other actions might also have had an influence.

\section{Consolidation}

During a consolidation process in a saturated soil some of the water in the voids will be squeezed out with a consequent decrease in the voids and therefore a decrease in the volume. The space between the grains is reduced, the interparticle forces increase and subsequently the strength of the soil increases.

Any action resulting in excess porewater pressure will start a consolidation process during which the effective stresses increase.

\section{Stresses in the soil}

The vertical stress is force per unit of area $(\mathrm{kPa})$. All stresses are measured relative to the atmospheric pressure.

The vertical total stress in the soil is the unit weight of the material multiplied by the depth below surface. The neutral stress is the unit weight of water multiplied by the depth below the water table.

If the water pressure is hydrostatic, the neutral stress is also the buoyancy on the soil material. The vertical effective stress, $\sigma^{\prime}$, is the vertical total stress, $\sigma$, reduced for the buoyancy, $u$.

$$
\sigma^{\prime}=\sigma-\mathrm{u}
$$

The effective stress is an expression of the forces between the grains in the soil. The effective stresses in the soil change if the load on the soil surface changes (change in the total stress, $\sigma$ ), or by changes in the water table (change in the neutral stress, $u$ ). Changes in the effective stresses are responsible for the deformations in the soils.

If a young soil never has been exposed to larger effective stresses than the actual stresses, the soil is denoted normally consolidated.

If a soil has been exposed to larger effective stresses than the actual stresses, the soil is denoted preconsolidated.

Creep in the material may cause an apparent preconsolidation.
The consolidation process

A load on the soil surface produces an increase in the vertical total stress, and excess water pressure is build up in the voids. During the dissipation of the excess pore water pressure the vertical effective stress increases and the voids (and then the volume) decrease. The duration of this consolidation process depends on the permeability of the soil.

If the load on the soil surface is removed, the total stress decreases, a low pressure appears in the voids and this is equalised by water flowing into the voids. The void ratio increases, but the increase in the void ratio is, however, not of the same order of magnitude as the decrease in the void ratio by the increase in the effective stress.

A soil in which the effective stress has once been larger than the present stress will therefore show smaller deformations by reloading and the soil is denoted preconsolidated. Deposits loaded by glaciers during the ice age are preconsolidated soils.

Preconsolidation of a soil could also be obtained by variations in the water table. Lowering of the water table introduces a decrease in the buoyancy, a consolidation process starts and the effective stress increases. If the water table rises again, the effective stress will be reduced and the soil is then preconsolidated.

During the geological periods and especially during the Late Weichselian, there have been many changes in the level of the water table relative to the soil surface, changes which might have caused a preconsolidation of the soils.

\section{Creep}

In addition to the consolidation deformations creep in the material will also take place by loading. Creep is a kind of plastic rearrangement of the flexible particles for a new load condition, and a gradual decrease in a diminutive excess pore water pressure takes place. At constant external load creep may cause an apparent preconsolidation of the sediment.

\section{Oedometer test}

\section{The oedometer test apparatus}

The actual oedometer tests were carried out using The Danish Oedometer Test Apparatus, which has a floating ring (Moust Jacobsen 1967). The registration of the deformations during the tests was automatic and continuous using transducers with an accuracy of $10^{-3}$ $\mathrm{mm}$. 


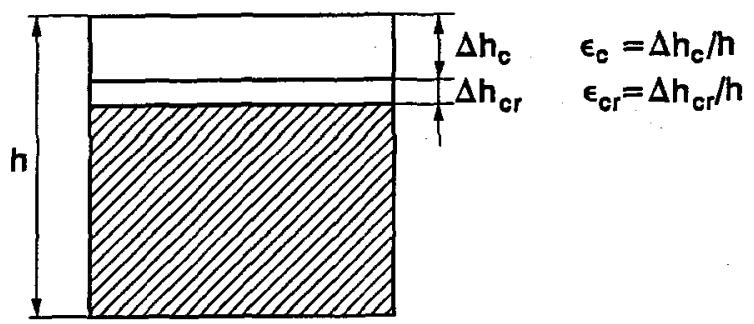

Fig. 2. Relative settlements, consolidation and creep strains.

\section{The test procedure}

The samples were extracted using a thin-walled sampler, $72 \mathrm{~mm}$ in diameter. The samples were shaped before being placed in the oedometer ring between the base and top cap. A porous stone in the base cap allows drainage. During the test the sample is subjected to a stepwise increase of the load and values of settlement and time are recorded for each load step.

Settlements in a saturated soil due to a load application can be divided into two different kinds, see Fig. 2:

1) $\Delta h_{c}$-settlements due to the consolidation process in the material

2) $\Delta \mathrm{h}_{\mathrm{cr}}$-settlements due to creep in the material.

The settlements will in the following be expressed as relative settlements, strains,

$$
\varepsilon=\Delta h / h
$$

where $h$ is the initial height of the sample.

Determination of the preconsolidation pressure Each time-strain curve contains consolidation strains as well as creep strains.

The creep strains have shown to vary rectilinear to $\log$ time after a certain period $d \varepsilon_{\mathrm{cr}}=\mathrm{Q}_{\mathrm{s}}$ dlog $\mathrm{t}$.

Moust Jacobsen (1992) formulated a model to separate creep and consolidation settlements during the consolidation process. He assumed the consolidation and creep to be simultaneous, and has described the creep as

$$
\varepsilon_{\mathrm{cr}}=\mathrm{Q}_{\mathrm{s}} \log \left(1+\mathrm{t}_{\mathrm{r}} / \mathrm{t}_{\mathrm{b}}\right)
$$

$\mathrm{Q}_{\mathrm{s}}$ is the rate of creep for $\sigma^{\prime}>\sigma_{\mathrm{pc}}$

$t_{t}$ is the real time passed

$t_{b}$ is a reference time

If the sample is under constant effective stress from a time $\mathrm{t}_{\mathrm{A}}$ to a time $\mathrm{t}_{\mathrm{A}}+\mathrm{t}$, the additional creep is

$$
\begin{aligned}
& \Delta \varepsilon=Q_{s} \log \left(1+\left(t_{A}+t\right) / t_{b}\right)-Q_{s} \log \left(1+t_{A} / t_{b}\right)=> \\
& \Delta \varepsilon=Q_{s} \log \left(1+t^{\prime}\left(t_{A}+t_{b}\right)\right)
\end{aligned}
$$

$t_{A}$ is the creep age, $t_{A}=0$ for a soil in a normally consolidated state.

The time-strain curves are separated in creep and consolidation as shown in Fig. 3.

The consolidation strain, $\varepsilon_{\mathrm{c}}$, and $\left(\mathrm{t}_{\mathrm{A}}+\mathrm{t}_{\mathrm{b}}\right)$ are determined for each load step.

For a preconsolidated soil the creep age will be reduced by each new load, and the preconsolidation pressure can be determined by the variation in creep age.

The effective stress, $\sigma$, plotted against the consolidation strain, $\varepsilon$, shows a rectilinear variation of $\varepsilon_{\mathrm{c}}$ with $\log \sigma^{\prime}$ for $\sigma^{\prime}$ larger than the original preconsolidation pressure, $\sigma^{\prime}$, as shown in Fig. 4 (Terzaghy 1947, Casagrande 1936).

$$
\mathrm{d} \varepsilon_{\mathrm{c}}=\mathrm{Qd} \log \sigma^{\prime}
$$

For a preconsolidated soil the modulus, $\mathrm{K}=\mathrm{d} \sigma / \mathrm{d} \varepsilon$, is nearly constant. When reaching $\sigma^{\prime}$, the modulus drops to the value for a soil in a normally consolidated state, and the variation is then proportional to the stress. From the variation in the modulus with $\sigma^{\prime}$, as shown in fig. $5, \sigma_{p c}$ can be determined within the load step, where the modulus drops to the value for a normally consolidated soil (Christensen \& Janbu 1992). The value for normally consolidated soil is shown as a dotted line in Fig. 5.

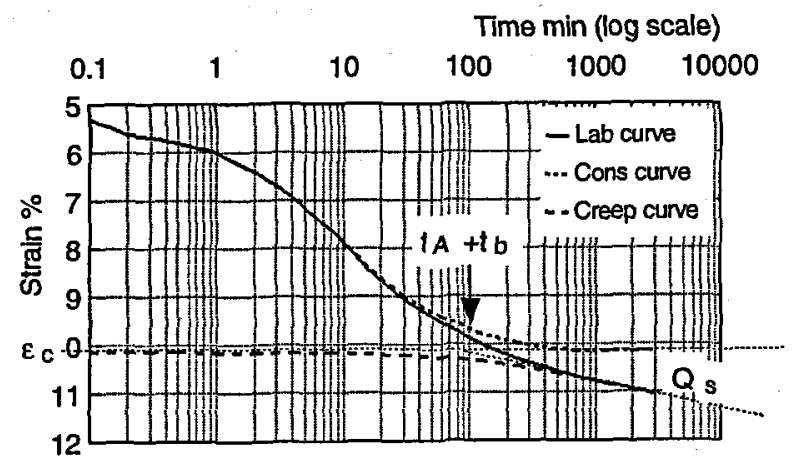

Fig. 3. Time-strain curve for a soil in a normally consolidated state $\left(t_{A}=0\right)$.

$$
\sigma_{\mathrm{pc}}^{\prime} \quad \sigma^{\prime} \mathrm{kPa} \text { (log scale) }
$$

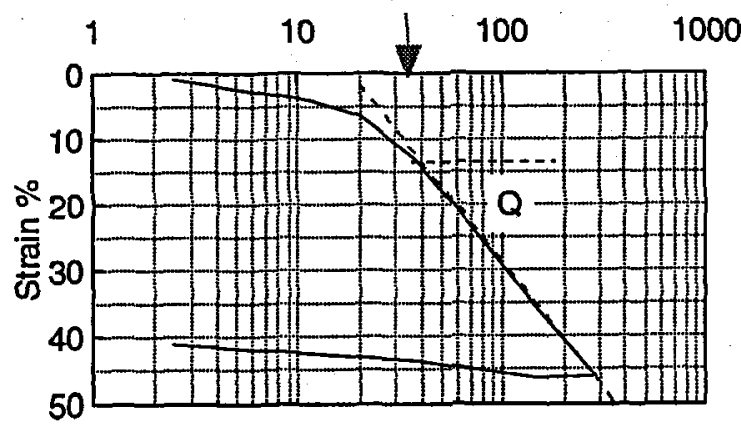

Fig. 4. Consolidation strain, $\varepsilon_{\mathfrak{c}}$, plotted against $\log \sigma^{\prime}$. 


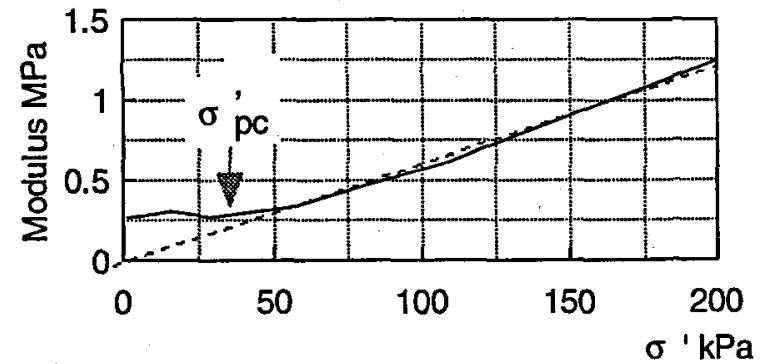

Fig. 5. Modulus, K, plotted against $\sigma$ '.

Determination of the influence of creep on the preconsolidation pressure

Moust Jacobsen (1992) assumed that the same value of the strain, $\varepsilon$, could be obtained in two ways as shown in Fig. 6:

1) a strain on the primary curve from $\sigma_{\mathrm{A}}^{\prime}$ to $\sigma_{\mathrm{pc}}$ (A' to $B$ )

$$
\Delta \varepsilon_{\mathrm{c}}=\mathrm{Q} \log \left(\sigma_{\mathrm{pc}}^{\prime} / \sigma_{\mathrm{A}}^{\prime}\right)
$$

2) a sum of a strain resulting from creep under constant stress to the time $t_{A}\left(A^{\prime}\right.$ to $A$ )

$$
\varepsilon_{\mathrm{cr}}=\mathrm{Q}_{\mathrm{s}} \log \left(1+\mathrm{t}_{\mathrm{A}} / \mathrm{t}_{\mathrm{b}}\right)
$$

and a strain by loading from $\sigma_{\mathrm{A}}^{\prime}$ to $\sigma_{\mathrm{pc}}^{\prime}$ (A to B)

$$
\Delta \varepsilon_{\mathrm{r}}=\left(\sigma_{\mathrm{pc}}^{\prime}-\sigma_{\mathrm{A}}^{\prime}\right) / \mathrm{K}
$$

where $\mathrm{K}$ is the average modulus at the "reloading" curve from A to B.

This leads to the following formula:

$$
\sigma_{\mathrm{pc}}^{\prime} / \sigma_{\mathrm{A}}^{\prime}=\left(1+\mathrm{t}_{\mathrm{A}} / \mathrm{t}_{\mathrm{b}}\right)^{\alpha} \exp \left(2.3\left(\sigma_{\mathrm{pc}}^{\prime}-\sigma_{\mathrm{A}}^{\prime}\right) / \mathrm{QK}\right)
$$

where $\alpha=Q_{\mathrm{s}} / \mathrm{Q}$, and $\sigma_{\mathrm{pc}^{\prime}} / \sigma_{\mathrm{A}}^{\prime}$ is the Over Consolidation Ratio, OCR.

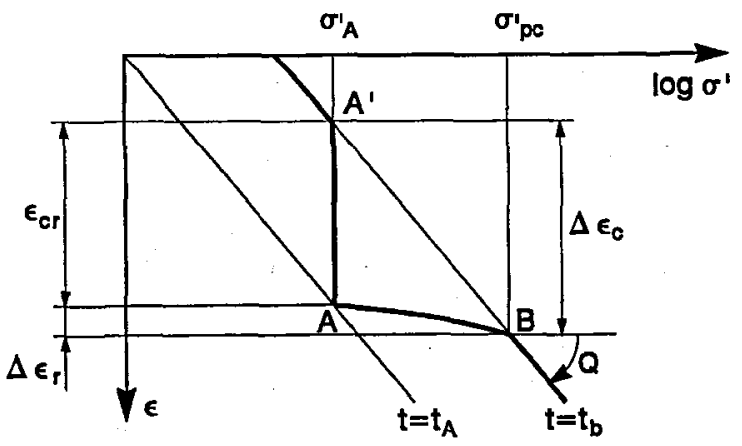

Fig. 6. Behaviour of a slightly preconsolidated clay (after Bjerrum 1967 and Moust Jacobsen 1992).
$\mathrm{Q}, \mathrm{Q}, \mathrm{K}$ and the apparent preconsolidation pressure, $\sigma^{\prime}$ c are found from the oedometer test, and if the in situ pressure $\left(\sigma^{\prime}\right)$ for the sample is known, the value for OCR can be determined.

The model set up by Moust Jacobsen has been used to analyse results from oedometer tests with different clays (Thorsen 1995a, b), and from these results it seems likely to assume, that the value $t_{b}$ is of the same magnitude as the time corresponding to about $90 \%$ consolidation.

From the time-strain curves in the oedometer tests the coefficient of consolidation, $c_{k}$, for the material is calculated, $c_{k}=k K / \gamma_{w}=T\left(H_{p}\right)^{2} / t$, where $T$ is the Terzaghi figure, which varies with the degree of consolidation ( $\mathrm{T} \sim \pi / 4$ for $89 \%$ consolidation) and $\mathrm{H}_{\mathrm{p}}$ is the drainage path, $\mathrm{k}$ is the hydraulic conductivity, $\mathrm{K}$ is the modulus and $\gamma_{w}$ is the unit weight of water.

If the thickness of the actual deposit, the drainage path and the creep age, $t_{A}$, are known, it is possible to estimate whether the creep alone could have caused the apparent preconsolidation pressure as determined from the oedometer test.

In the following the results from oedometer tests with the two samples from Hollerup and the two samples from Sols $\varnothing$ are analysed as outlined above in an attempt to make a contribution to the estimation of the stress history during the Weichselian.

\section{Hollerup}

\section{The profile}

In the kieselguhr pit at Hollerup a profile of Eemian deposits is exposed for research projects. The Eemian profile shows $4 \mathrm{~m}$ fresh-water calcareous clay-mud and $5 \mathrm{~m}$ diatomaceous mud overlain by about $10 \mathrm{~m}$ of sand deposits from Weichselian (Larsen \& Kronborg 1994).

To protect the profile a little woodshed has been constructed around the place. Unfortunately the profile was not so very clean in April 95, when we arrived at the pit. It was therefore only possible to extract samples from the calcareous clay-mud.

\section{The tested samples}

For oedometer tests two samples were extracted from the slope in the pit. The sample named Hollerup 1, was extracted from the slope at the same level as the roof of the woodshed, Fig. 7, and the sample named Hollerup 2 was extracted about $1 \mathrm{~m}$ below the roof, Fig. 8. 


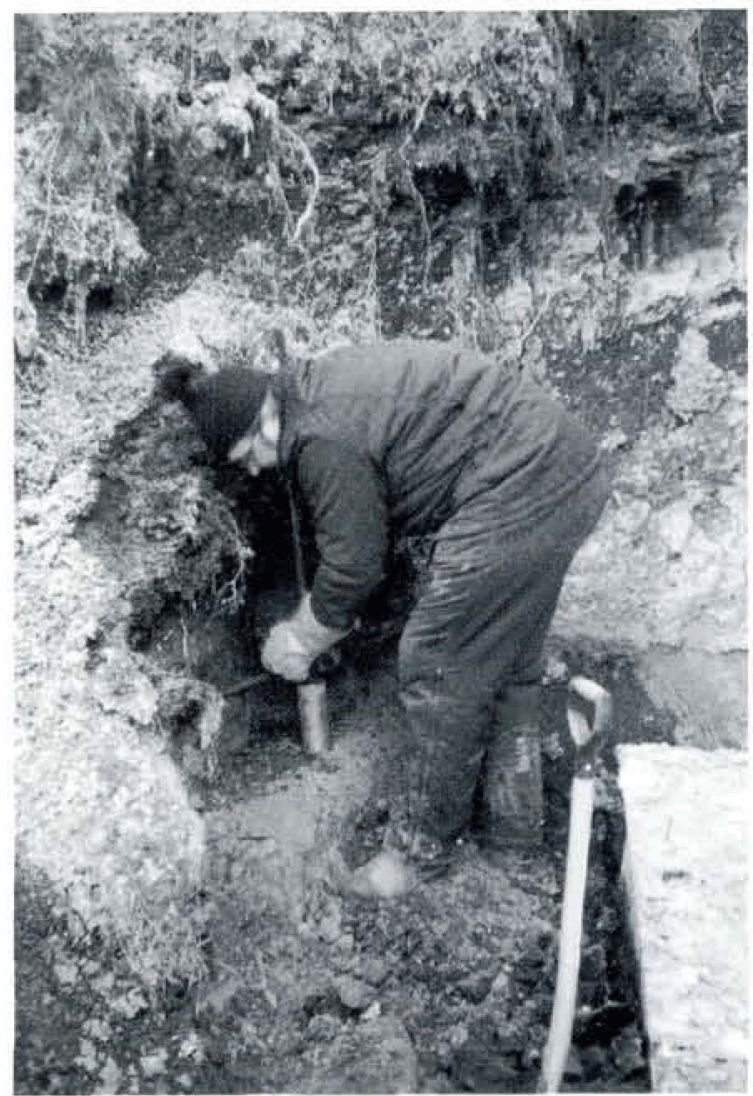

Fig. 7. Location of Hollerup 1.

Classification tests with the material have given the following results:

$\begin{array}{lll} & \text { Hollerup 1 } & \text { Hollerup 2 } \\ \text { water content } \% & \mathrm{w}=63.8 & \mathrm{w}=67.2 \\ \text { unit weight } \mathrm{kN} / \mathrm{m}^{3} & \gamma=15.2 & \gamma=15.3 \\ \text { lime content } \% & \mathrm{ka} \sim 86 & \mathrm{ka} \sim 80 \\ \text { loss on ignition } \% & \mathrm{gl} \sim 8 & \mathrm{gl} \sim 8\end{array}$

Since the samples were extracted from the slope of the pit, it is a little difficult to determine the value of the effective stress in situ. The Eemian deposits are, however, overlain by about $10 \mathrm{~m}$ of meltwater deposits. In the calculation of the OCR-value the effective stress in situ is therefore estimated to about $\sigma^{\prime} \sim 200 \mathrm{kPa}$ as a supposed maximum value.

\section{Results of oedometer tests}

For each time-strain curve the creep strain is subtracted from the measured strain and the values of $\varepsilon_{\mathrm{c}},\left(\mathrm{t}_{\mathrm{A}}+\mathrm{t}_{\mathrm{b}}\right)$ and the modulus, $\mathrm{K}$, are determined. Fig. 9 shows $\varepsilon_{\mathrm{c}}$ against $\log \sigma^{\prime}$,

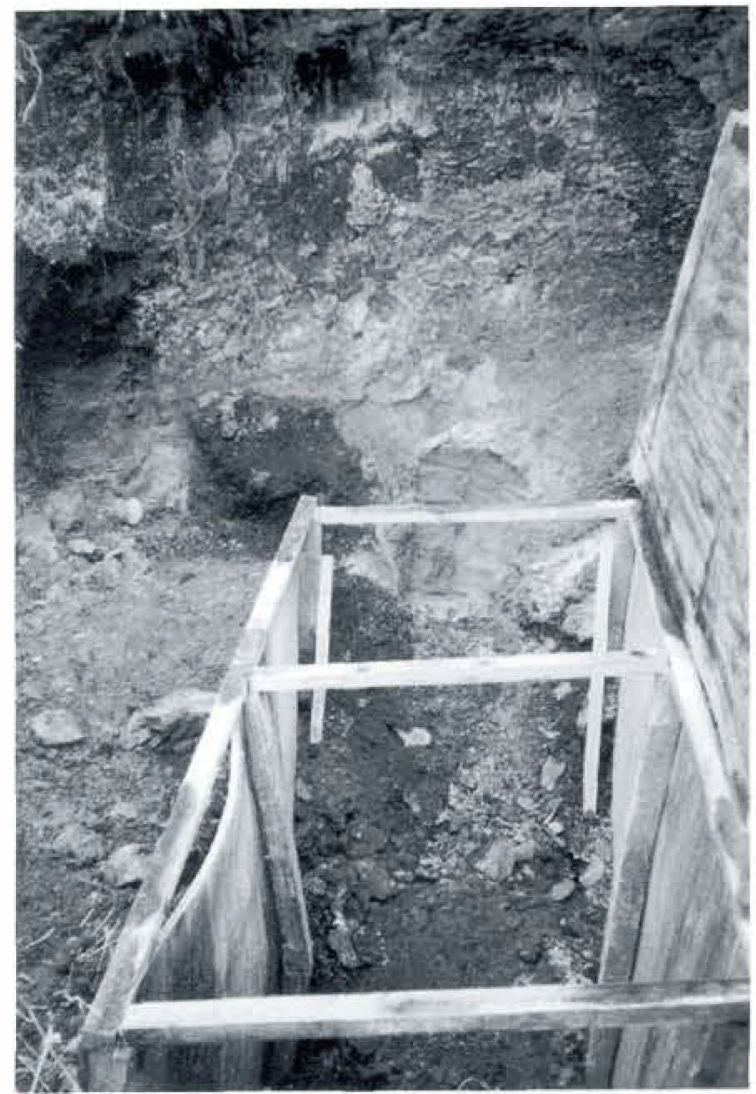

Fig. 8. Location of Hollerup 2.

The variation in $\left(t_{A}+t_{b}\right)$ with the effective stress, $\sigma^{3}$ is shown in Figs 10 and 11 shows the modulus, $\mathrm{K}$, against $\sigma^{\prime}$,

During the test with Hollerup 1 the effective stress was decreased from 2.1 to $1.4 \mathrm{MPa}$, and the reloading curve from 1.4 MPa showed an apparent preconsolidation of about $3.2 \mathrm{MPa}$, as shown with a dotted arrow at Figs 10 and 11.

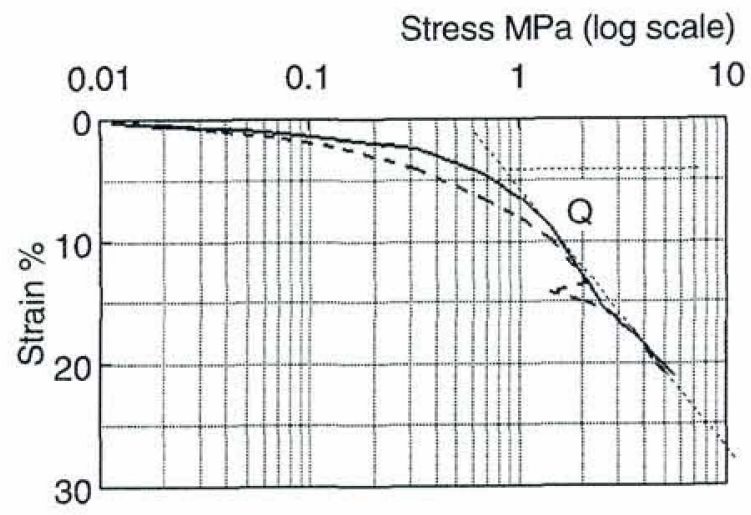

Fig. 9. Hollerup 1 and 2. $\varepsilon$ plotted against $\log \sigma^{\prime}$. 
$\mathrm{t}_{\mathrm{A}}+\mathrm{t}_{\mathrm{b}} \min$

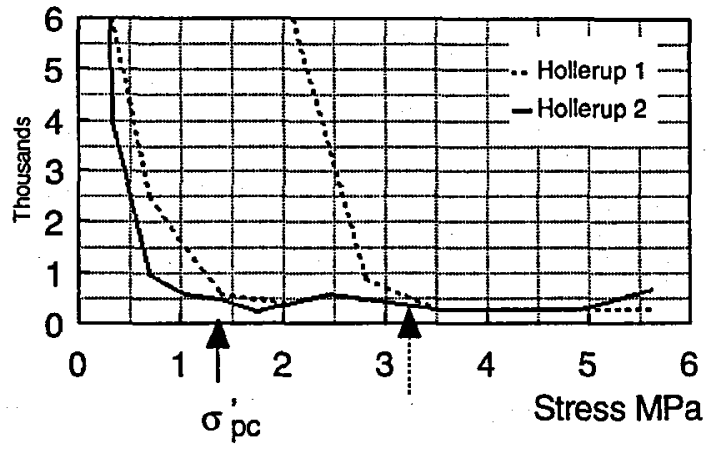

Fig. 10. Hollerup 1 and 2. $\left(t_{A}+t_{b}\right)$ plotted against the effective stress, $\sigma$ '.

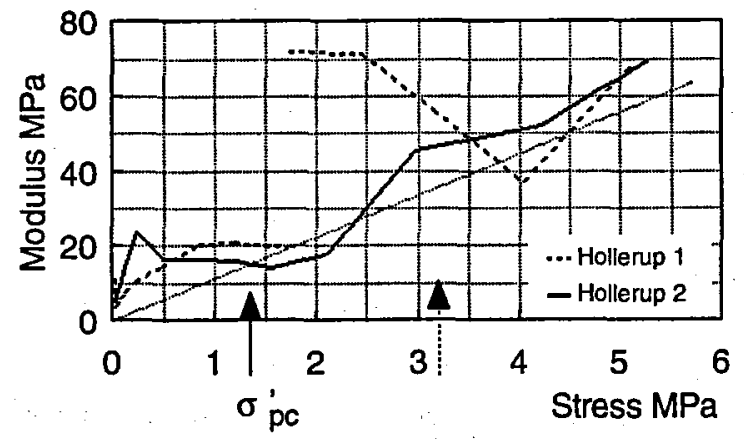

Fig. 11. Hollerup 1 and 2. Modulus, $K$, plotted against the effective stress, $\sigma$ '.

The results of the oedometer tests are the following:

$$
\begin{aligned}
& \mathrm{Q} \sim 20 \% \\
& \sigma^{\prime} \sim 1.4 \mathrm{MPa} \\
& \mathrm{K}^{\mathrm{pc}} \sim 18 \mathrm{MPa} \text { for } \sigma^{\prime}<\sigma_{\mathrm{pc}}^{\prime} \\
& \mathrm{Q}_{\mathrm{s}} \sim 1.2 \%, \\
& \alpha=\mathrm{Q}_{\mathrm{s}} / \mathrm{Q}=0.06 \\
& \mathrm{c}_{\mathrm{k}} \sim 5 \times 10^{-8} \mathrm{~m}^{2} / \mathrm{sec} \\
& \mathrm{t}_{\mathrm{b}} \sim 300 \mathrm{~min}
\end{aligned}
$$

Assuming the in situ stress to $\sigma^{\prime}<200 \mathrm{kPa}$, gives $\sigma_{\mathrm{pc}}^{\prime} / \sigma^{\prime}{ }_{\mathrm{o}}=$ OCR $>7$

From the reloading curve to $2.1 \mathrm{MPa},\left(\mathrm{t}_{\mathrm{A}}+\mathrm{t}_{\mathrm{b}}\right)$ is determined to about $6000 \mathrm{~min}$ as shown in Fig. 12. The creep age, $t_{A}$, is then $5700 \mathrm{~min}$.

The apparent preconsolidation pressure is determined to $3.2 \mathrm{MPa}$, see Figs 10 and 11. OCR 3.2/2.1 = 1.52, and from formula (6):

$$
\begin{aligned}
& \text { OCR } \sim(1+5700 / 300)^{0.06} \exp (2.3 \times 1.1 / 0.2 \times 53) \\
& \text { OCR } \sim 1.52
\end{aligned}
$$

The calculated value and the observed value from the consolidation test are the same, which means that the formula (6) seems to give relevant results.

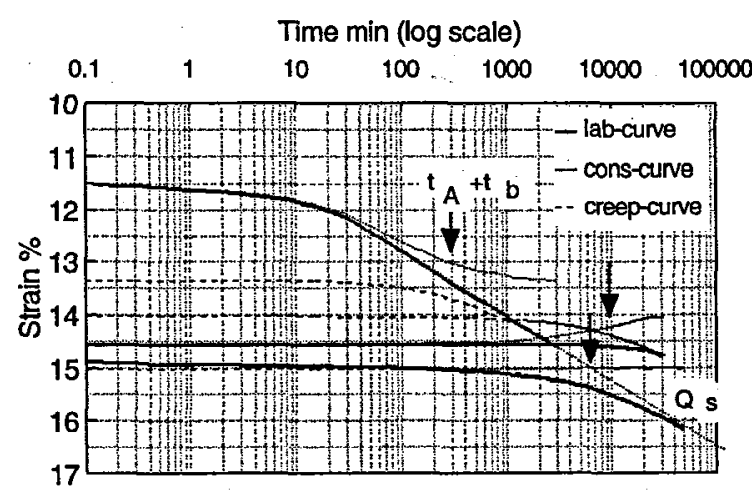

Fig. 12. Hollerup 1. Time-strain curves for loading to 2.1 $\mathrm{MPa}\left(\mathrm{t}_{\mathrm{A}}=0, \mathrm{t}_{\mathrm{b}}=300 \mathrm{~min}\right)$, unloading to $1.4 \mathrm{MPa}\left(\mathrm{t}_{\mathrm{A}}+\mathrm{t}_{\mathrm{b}}=\right.$ $10000 \mathrm{~min}$ ) and reloading to $2.1 \mathrm{MPa}\left(\mathrm{t}_{\mathrm{A}}+\mathrm{t}_{\mathrm{b}}=6000 \mathrm{~min}\right)$.

\section{Calculated OCR-value from creep only}

The thickness of the layer is $9 \mathrm{~m}$. An estimation of the drainage path to $4.5 \mathrm{~m}$, gives:

$\mathrm{t} \sim \operatorname{Tx}(4.5)^{2} / 5 \times 10^{-8} \mathrm{sec}$

$\mathrm{t}_{\mathrm{b}} \sim 10$ years for $\mathrm{T}=\pi / 4$

Assuming the creep age is equal to the geological age, $t_{A} \sim 12 \times 10^{4}$ years, formula (6) will give:

$$
\begin{aligned}
& \sigma_{\mathrm{pc}}^{\prime} / \sigma_{0}^{\prime} \sim\left(1+12 \times 10^{4} / 10\right)^{0.06} \exp \left(2.3 \times\left(\sigma_{\mathrm{pc}}^{\prime}-\sigma_{0}^{\prime}\right) / 0.2 \times 18\right) \\
& =>\sigma_{\mathrm{pc}}^{\prime} \sim 0.4 \mathrm{MPa}=>\text { OCR } \sim 2
\end{aligned}
$$

If the meltwater sand from an ice sheet in Weichselian is from about 50000 years ago and the deposition of the sand has reduced the creep age to zero, formula (6) will give

$\sigma_{p c}^{\prime} \sim 0.37 \mathrm{MPa}=>$ OCR $\sim 1.85$

As expected for samples from a layer of Eemian deposits east of the main stationary line in the Weichselian, the value OCR $\sim 7$ determined from the oedometer test is much higher than the calculated value for OCR from (6). The apparent OCR-value could not be caused only by creep since deposition of the material. Other actions must have had an influence on the preconsolidation pressure. 


\section{Sols $\varnothing$}

\section{The profile}

The Eemian bog-deposits have been investigated and described by Jessen \& Milthers (1928) and Larsen \& Kronborg (1994).

In May 1995 a boring was carried out and undisturbed samples were extracted from the Eemian deposits. The position of the boring correlated to the previous investigations is shown in Figs 13 and 14. The result of the boring is seen in Fig. 15.

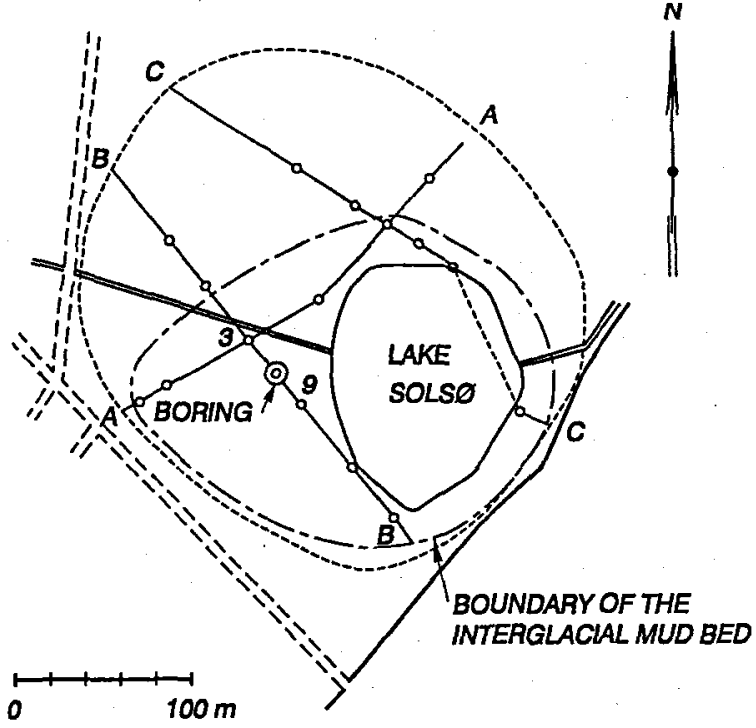

Fig. 13. Site plan. Solsø (Jessen \& Milthers 1928) and the position of the actual boring.

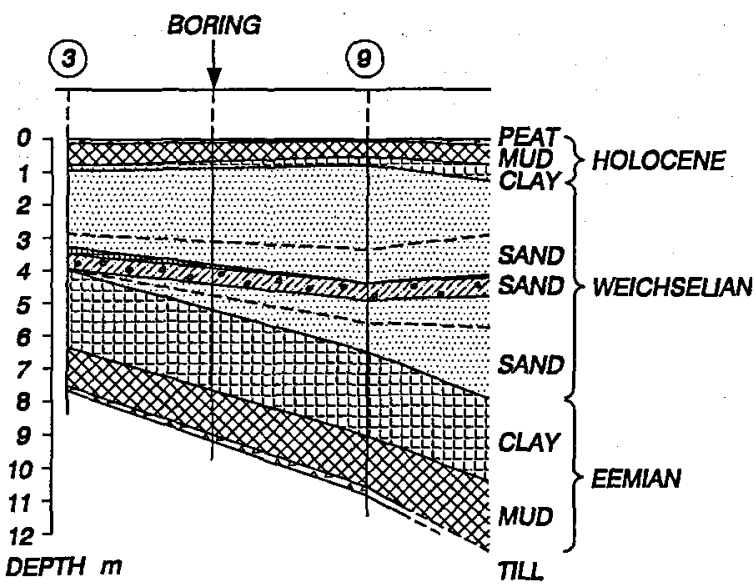

Fig. 14. Part of section B-B (Fig. 13) Solsø (Jessen \& Milthers 1928) and the position of the actual boring.
The boring

The material from the boring has not been described by a geologist, but if we compare the results from the boring (Fig. 15) with the previous geological descriptions, the conclusion is that Eemian deposits are found from $5.2 \mathrm{~m}$ to $9.2 \mathrm{~m}$ below the surface.

Undisturbed samples for oedometer tests have been extracted from the Eemian deposits of clay and mud. Oedometer tests have been carried out with Sols $\varnothing 13$ from $6.8 \mathrm{~m}$ below the surface and Sols $\varnothing 17$ from $8.5 \mathrm{~m}$ below the surface.

Classification tests for the material have given the following results:

$\begin{array}{lll} & \text { Solsø 13 } & \text { Sols } \varnothing 17 \\ \text { water content } \% & \mathrm{w}=56.7 & \mathrm{w}=77.7 \\ \text { unit weight, } \mathrm{kN} / \mathrm{m}^{3} & \gamma=15.8 & \gamma=13.5 \\ \text { lime content } \% & \mathrm{ka} \sim 0 & \mathrm{ka} \sim 0 \\ \text { loss on ignition } \% & \mathrm{gl} \sim 7 & \mathrm{gl} \sim 17\end{array}$

After the boring was finished a stand pipe was installed in the bore hole, and the water level was measured to be about $0.8 \mathrm{~m}$ below the soil surface. The in situ pressure is estimated to:

$\sigma_{0}^{\prime} \sim 60 \mathrm{kPa}, 6.8 \mathrm{~m}$ below the surface, and $\sigma_{0}^{\prime} \sim 70 \mathrm{kPa}, 8.5 \mathrm{~m}$ below the surface.

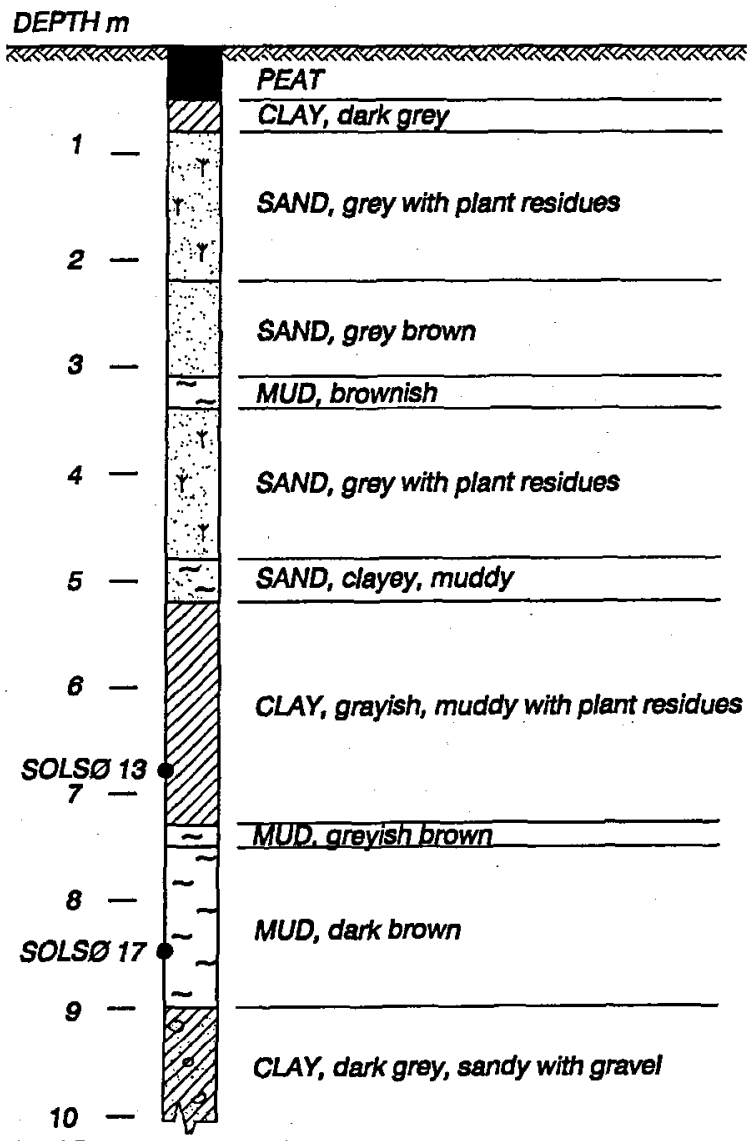

Fig. 15. The actual boring at Sols $\varnothing$. 
Sols $\emptyset 13$ and 17. Results of oedometer tests

For each time-strain curve the creep strain is subtracted from the lab-curve and the values of $\varepsilon_{c},\left(t_{A}+t_{b}\right)$ and the modulus, $K$, are determined. Fig. 16 shows $\varepsilon_{c}$ against $\log \sigma^{\prime}$, Fig. 17 shows the variation in $\left(t_{A}+t_{b}\right)$ with the effective stress, $\sigma$ ' and Fig. 18 shows K against $\sigma$ '.

\section{Stress MPa (log scale)}

0.01

0.1

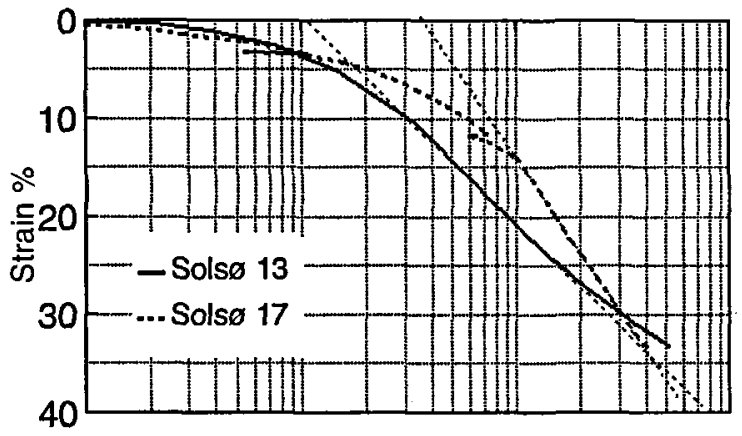

Fig. 16. Sols $\varnothing 13$ and $17, \varepsilon_{\mathrm{c}}$ plotted against $\log \sigma^{\prime}$.

$t_{A}+t_{b}(\min )$

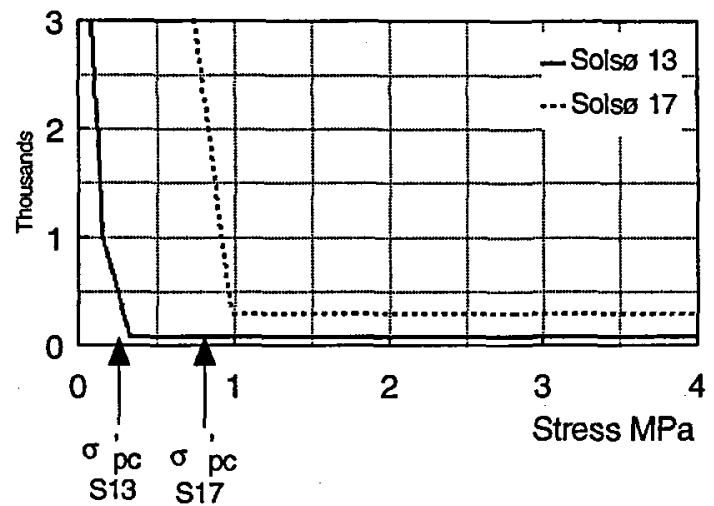

Fig. 17. Sols $\varnothing 13$ and 17. $\left(t_{A}+t_{b}\right)$ plotted against the effective stress, $\sigma^{\prime}$.

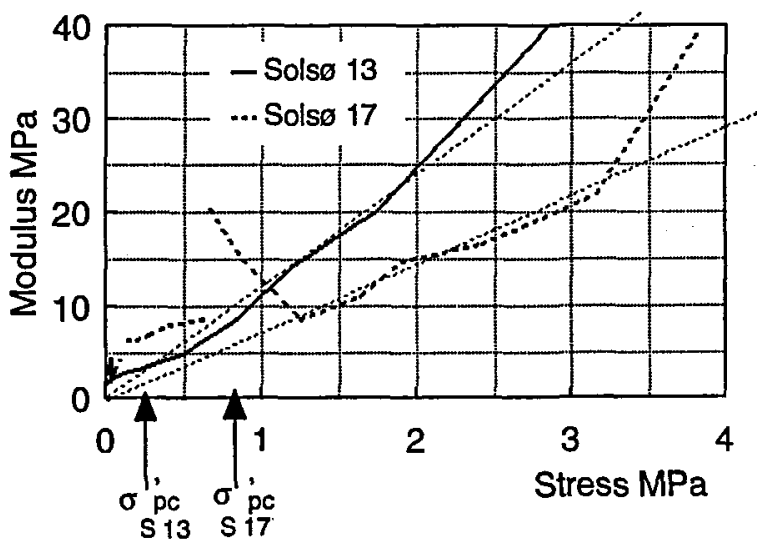

Fig. 18. Sols $\varnothing 13$ and 17. Modulus, K, plotted against the effective stress, $\sigma$ '.
The results of the oedometer tests are the following:

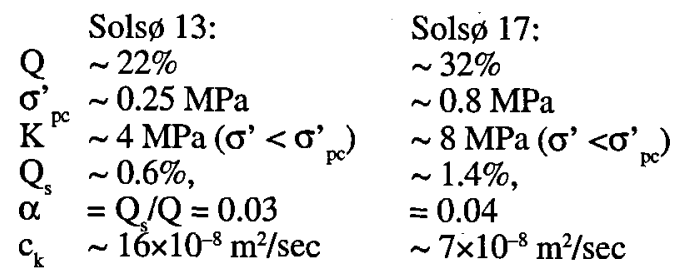

Assuming the in situ stress to $\sigma^{\prime} \sim 0.06 \mathrm{MPa}$ for Sols $\varnothing$ 13 and $\sigma_{0}^{\prime} \sim 0.07 \mathrm{MPa}$ for Sols $\varnothing 17$ gives OCR $\sim 4$ and $\mathrm{OCR} \sim 10$ respectivly.

Calculated OCR-values from creep only

Clay 5.2-7.3 m below surface (Solsø 13)

The thickness of the layer is $2.1 \mathrm{~m}$, but since the total thickness of the clay and mud layers is $3.8 \mathrm{~m}$, and the underlying mud layer has a lower hydraulic conductivity, the drainage path is estimated to the thickness of the layer, $2.1 \mathrm{~m}$, which gives:

$\mathrm{t} \sim \mathrm{T}(2.1)^{2} / 16 \times 10^{-8} \mathrm{sec}$

$t_{b} \sim 0.69$ years for $T=\pi / 4$

Assuming the creep age is equal to the geological age, $t_{A} \sim 12 \times 10^{4}$ years, formula (6) gives:

$\sigma_{\mathrm{pc}^{\prime}} / \sigma_{0}^{\prime} \sim\left(1+12 \times 10^{4} / 0.69\right)^{0.03} \exp \left(2.3 \times\left(\sigma^{\prime}{ }_{\mathrm{pc}}-\sigma_{0}^{\prime}\right) / 0.22 \times 4\right)$

$=>\sigma^{\prime}{ }_{p c} \sim 0.094=>$ OCR $\sim 1.57$

If the creep age is reduced to 50.000 years the calculated values from (6) are:

$\sigma_{\mathrm{pc}}^{\prime} \sim 0.091=>$ OCR $\sim 1.52$

Mud 7.3-9 $\mathrm{m}$ below surface, (Solsø 17)

The thickness of the layer is $1.7 \mathrm{~m}$, with $\mathrm{H}_{\mathrm{D}} \sim 1.7 \mathrm{~m}$, we get

$\mathrm{t} \sim \operatorname{Tx}(1.7)^{2} / 7 \times 10^{-8} \mathrm{sec}$

$\mathrm{t}_{\mathrm{b}} \sim 1.03$ years for $\mathrm{T}=\pi / 4$

and then from formula (6) if the creep age $t_{A} \sim 12 \times 10^{4}$ years:

$\sigma_{\mathrm{pc}} / \sigma_{0} \sim\left(1+12 \times 10^{4} / 1.03\right)^{0.04} \exp \left(2.3 \times\left(\sigma_{\mathrm{pc}}^{\prime}-\sigma_{0}^{\prime}\right) / 0.32 \times 8\right)$

$\Rightarrow \sigma_{\mathrm{pc}}^{\prime} \sim 0.116=>$ OCR $\sim 1.66$

If the creep age is reduced to 50.000 years the calculated values from (6) are:

$\sigma_{\mathrm{pc}} \sim 0.112 \Rightarrow$ OCR $\sim 1.6$ 
For both samples the value of OCR $\sim 4$ and OCR $\sim 10$ as determined from the oedometer test is much higher than the calculated value for OCR from (6). The apparent OCR-value could not be caused only by creep since deposition of the material. Other actions must have had an influence on the preconsolidation pressure.

\section{Concluding remarks}

For the samples from Hollerup as well as the samples from Sols $\varnothing$ the OCR value determined from the oedometer test is much higher than the expected value for OCR due to creep in the material since deposition, so other actions must have had an influence on the preconsolidation pressure.

The main influence on the calculated values of $O C R$ is due to:

1) The determined value for $\sigma_{\mathrm{pc}}$. The oedometer tests have been carried out with stepwise load increments. The determination of the preconsolidation pressure is therefore subject to some uncertainty depending on the magnitude of the load step, but even the most pessimistic value of $\sigma_{\mathrm{pc}}$ estimated from the oedometer test will not change the result considerably.

2) The estimated length of the drainage path. It is very difficult to estimate the length of the drainage path, $\mathrm{H}_{\mathrm{D}}$, in the deposit. $\mathrm{H}_{\mathrm{D}}$ has a major influence on the calculated time $t$ and therefore also on the calculated value of OCR due to creep.

The table below shows the following:

1) $O C R_{0}$ - determined from oedometer test

2) $\mathrm{OCR}_{b 1}^{o}$ - from (6) $t_{A}=120.000$ years

3) $\mathrm{OCR}_{\mathrm{b} 2}$ - from (6) $\mathrm{t}_{\mathrm{A}}=50.000$ years

4) $w \%{ }^{2}$ - water content

5) ka\% - lime content

6) $\mathrm{gl} \% \quad$ - loss on ignition.

\begin{tabular}{|l|l|l|l|}
\hline & $\begin{array}{l}\text { Hollerup } \\
\text { 1 and 2 }\end{array}$ & Solsø 13 & Solsø 17 \\
\hline 1) $\mathrm{OCR}_{\mathrm{o}}$ & 7 & 4 & 10 \\
2) $\mathrm{OCR}_{\mathrm{b} 1}$ & 2 & 1.58 & 1.66 \\
3) $\mathrm{OCR}_{\mathrm{b} 2}$ & 1.85 & 1.53 & 1.6 \\
4) $\mathrm{w} \%$ & $64-67$ & 57 & 78 \\
5) $\mathrm{ka} \%$ & 80 & 0 & 0 \\
6) $\mathrm{gl} \%$ & 8 & 7 & 17 \\
\hline
\end{tabular}

The results do not show any significant difference in the determined values of OCR from Hollerup and Solsø. The largest difference is in the results of the two samples from Solsø.
For all the tested samples the values of OCR found from the oedometer tests are larger than what could be expected from creep alone, but the results tell nothing about the kind of actions, which have caused the overconsolidation.

For the samples from Hollerup it seems most likely that the determined preconsolidation pressure is caused by an ice cap during Weichselian.

For the samples from Sols $\varnothing$ it is more difficult. The determined preconsolidation pressure might be due to a previous ice cap, but the big difference in the determined preconsolidation pressures for the two samples from the same boring might indicate an influence also from other processes.

The sediments from Hollerup and Sols $\varnothing$ are not identical, and no attempt has been made to evaluate the influence on the apparent preconsolidation pressure due to temperature or chemical and biological processes in the material.

In organic soils a decomposition and humification of the organic material takes place and often also a gassification. These processes will undoubtly have an influence on the apparent preconsolidation pressure determined in an oedometer test. An investigation concerning this phenomenon is in progress.

\section{Acknowledgements}

The author gratefully acknowledges the help from Knud Fredslund, Kampsax-Geodan, Holstebro, who kindly carried out the boring at Solsø for this purpose.

\section{Dansk sammendrag}

Geologiske unders $ø$ gelser af Larsen \& Kronborg (1994) omkring iskappernes udbredelse i Weichsel istiden tyder på, at Eem aflejringer i Midt- og Vestjylland har været isdækket under de første isfremstød.

Formålet med den aktuelle undersøgelse har været at undersøge om konsolideringsforsøg med relativt ensartede Eem aflejringer fra henholdsvis øst og vest for hovedopholdslinien ville vise en markant forskel i den ud fra fors $\varnothing$ gene bestemte forbelastningsspænding.

Der er udført konsolideringsfors $\varnothing \mathrm{g}$ med to prøver af kalkgytje fra Hollerup, øst for hovedopholdslinien, og prøver af gytjeholdig ler og gytje fra Solsø, vest for hovedopholdslinien. Materialerne var desværre ikke helt ensartede, forskellige kemiske og biologiske omdannelsesprocesser som medvirkende årsag til den konstaterede forbelastningsspænding kan derfor ikke udelukkes.

I 1992 opstillede Moust Jacobsen en model til adskillelse af krybningst $\varnothing j n i n g e r$ og konsolideringstøjninger under konsolideringsprocessen. Modellen var 
udviklet for lettere forbelastet moræneler, men har også været anvendt for andre lerarter. Resultaterne af de aktuelle konsolideringsfors $\varnothing \mathrm{g}$ er behandlet ud fra denne model, ligesom modellen er benyttet til at vurdere, om de ved forsøgene konstaterede forbelastninger kunne være opnået alene ved krybning i materialerne siden aflejringstidspunktet.

Resultaterne af fors $\varnothing$ gene viser ingen markant forskel i de bestemte OCR-værdier fra henholdsvis Hollerup, OCR $\sim 7$, og Solsø, OCR 4 og 10, idet den største forskel i OCR-værdier er fundet ved de to fors $\varnothing \mathrm{g}$ fra Solsø.

For alle fire prøver er ved fors $\emptyset$ gene bestemt en OCRværdi, som er meget større end den OCR-værdi som kunne forventes alene ved krybning i materialerne fra aflejringstidspunktet.

For prøverne fra Hollerup synes det naturligt at antage, at den fundne forbelastning skyldes et isdække under Weichsel istiden.

For prøverne fra Solsø er det mere vanskeligt. Den konstaterede forbelastning kan skyldes belastning fra et tidligere isdække, men den konstaterede store forskel i forbelastningsspænding på de to prøver fra samme boring indicerer en indflydelse også fra andre processer.

Der er ikke i denne undersøgelse gjort noget forsøg på at vurdere indflydelse fra temperatur eller kemiske og biologiske processer på den fundne tilsyneladende forbelastningsspænding i materialerne.

\section{References}

Bjerrum, L. 1967. Engineering geology of the Norwegian Normally Consolidated Marine Clays as Related to Settlements of Buildings. Geotechnique 17, 81-118.

Casagrande, A. 1936. The determination of the preconsolidation pressure and its significance. Proceedings of the International conference on soil Mechanics and Foundation Engineering, IICSMFE Cambridge, Vol. 3, 60-64.

Christensen, S. \& N. Janbu, 1992. Ødometerforsøg - et primærkrav i praktisk geoteknik. (Oedometer tests - a primary requirement in practical soil mechanics). Proceedings fra Nordisk Geoteknikermøde, NGM-92, Aalborg, Danish Geotechnical Society, Bulletin 9, Vol. 2. 449-454.

Jessen, K. \& V. Milthers. 1928. Stratigraphical and Paleontological Studies of Interglacial Fresh-water Deposits in Jutland and Northwest Germany. The Geological Survey of Denmark, II. rk. no. 48. Reitzel.

Larsen, G. \& C. Kronborg, 1994. Geologisk set. Det mellemste Jylland. En beskrivelse af områder af national geologisk interesse. Geografforlaget. Miljøministeriet. Skovog Naturstyrelsen.

Moust Jacobsen, H. 1967. Morænelers geotekniske Egenskaber. (The geotechnical properties of clay till). Ph.D.thesis 1967. Reprinted 1994. Aalborg University.

Moust Jacobsen, H. 1992a. Bestemmelse af forbelastningstryk i laboratoriet. (Determination of preconsolidation pressure in the laboratory). Proceedings fra Nordisk Geoteknikermøde, NGM-92, Aalborg, Danish Geotechnical Society, Bulletin 9, Vol. 2, 455-460).

Moust Jacobsen, H. 1992b. Karakteristiske belastningstilstande for moræneler. Characteristic stress conditions for clay till). Proceedings fra Nordisk Geoteknikermøde, NGM-92, Aalborg, Danish Geotechnical Society, Bulletin 9, Vol. 2, 461-466.

Terzaghi, K. 1947. Theoretical Soil Mechanics. Wiley. New York.

Thorsen, G. 1995a. Preconsolidation pressure and creep settlements - estimations based on oedometer tests. Balkema. Proceeding of the International Symposium on Compression and Consolidation of Clayey Soils, IS-HIROSHIMA'95. Vol 1, 287-292.

Thorsen. G. 1995b. The Skaw Spit - a question of settlements. Proceedings of the Eleventh European Conference on Soil Mechanics and Foundation Engineering, XI ECSMFE, Copenhagen, Danish Geotechnical Society, Bulletin 11, Vol. 3, 263-268. 